\title{
The extremely conserved amino terminus of RAD6 ubiquitin-conjugating enzyme is essential for amino-end rule-dependent protein degradation
}

\author{
John F. Watkins, Patrick Sung, ${ }^{1}$ Satya Prakash, ${ }^{1}$ and Louise Prakash \\ Department of Biophysics, University of Rochester School of Medicine, Rochester, New York 14642 USA; ${ }^{1}$ Department \\ of Biology, University of Rochester, Rochester, New York 14627 USA
}

\begin{abstract}
The RAD6 gene of Saccharomyces cerevisiae encodes a ubiquitin-conjugating enzyme that is required for DNA repair, damage-induced mutagenesis, and sporulation. In addition, RAD6 mediates the multiubiquitination and degradation of amino-end rule protein substrates. The structure and function of RAD6 have been remarkably conserved during eukaryotic evolution. Here, we examine the role of the extremely conserved amino terminus, which has remained almost invariant among RAD6 homologs from yeast to human. We show that RAD6 is concentrated in the nucleus and that the amino-terminal deletion mutation, rad6 $_{\Delta 1-9}$, does not alter the location of the protein. The amino-terminal domain, however, is essential for the multiubiquitination and degradation of amino-end rule substrates. In the rad6 $_{\Delta 1-9}$ mutant, $\beta$-galactosidase proteins bearing destabilizing amino-terminal residues become long lived, and purified rad6 $_{\Delta 1-9}$ protein is ineffective in ubiquitin-protein ligase (E3)-dependent protein degradation in the proteolytic system derived from rabbit reticulocytes. The amino terminus is required for physical interaction of RAD6 with the yeast $U B R 1$-encoded E3 enzyme, as the rad6 I1-9 $_{1}$ protein is defective in this respect. The rad6 ${ }_{\Delta 1-9}$ mutant is defective in sporulation, shows reduced efficiency of DNA repair, but is proficient in UV mutagenesis. E3-dependent protein degradation by RAD6 could be essential for sporulation and could affect the efficiency of DNA repair.
\end{abstract}

[Key Words: RAD6 gene; Saccharomyces cerevisiae; ubiquitin-conjugating enzyme; amino-end rule protein]

Received

The RAD6 gene of Saccharomyces cerevisiae is required for DNA repair, DNA damage-induced mutagenesis, and sporulation. rad6 mutants are highly sensitive to killing by a variety of DNA damaging agents, including ultraviolet light (UV), $\gamma$-rays, and alkylating agents, and they are defective in postreplication repair of gaps that arise in newly synthesized DNA across from the damage sites in UV-irradiated DNA. In addition, rad6 mutants are defective in damage-induced mutagenesis and sporulation (for review, see Prakash et al. 1990).

$R A D 6$ encodes a 172 -residue, $20-\mathrm{kD}$ protein containing a globular domain comprising approximately the first 149 amino acids and an extended carboxy-terminal tail in which 20 of the 23 residues are acidic (Morrison et al. 1988). RAD6 is a ubiquitin conjugating enzyme, and in vitro it has been shown to multiubiquitinate histones H2A, H2B, and H3 (Jentsch et al. 1987; Sung et al. 1988; Haas et al. 1990). The carboxy-terminal acidic domain is required to target RAD6 to histones (Sung et al. 1988). The rad6-149 mutant, missing the entire acidic tail domain, is defective in sporulation but proficient in DNA repair and mutagenesis (Morrison et al. 1988). Muta- tional inactivation of the active site Cys- 88 residue results in a Rad6 protein devoid of any ubiquitin-conjugating ability, and these mutants resemble the rad6 null mutant in defects in DNA repair, mutagenesis, and sporulation, indicating that all of the biological functions of RAD6 are mediated by its ubiquitin-conjugating activity (Sung et al. 1990).

More recently, RAD6 has been shown to function in the protein degradation pathway dependent on the identity of the amino-terminal residue. The amino termini of potential proteolytic substrates are first recognized by a protein variously referred to as ubiquitin-protein ligase, E3, or N-recognin. Both yeast and mammalian E3 proteins contain a binding site for type I substrates and another site for type II substrates. Type I protein substrates have a basic residue, Arg, Lys, or His, at their amino termini, and type II substrates have a bulky hydrophobic residue, Phe, Trp, Tyr, or Leu, at their amino termini (for review, see Finley and Chau 1991; Hershko 1991). In addition, E3 interacts with a region in the body of the proteolytic substrate. Studies from several laboratories have demonstrated a role of RAD6 in E3-dependent ubiq- 
uitination and protein degradation in yeast as well as in mammals. Purified yeast RAD6 protein catalyzes multiubiquitination and degradation of protein substrates with destabilizing amino termini in reaction mixtures containing ubiquitin activating enzyme (E1), E3, and the ubiquitin-specific protease from rabbit reticulocytes (Sung et al. 1991). In S. cerevisiae, UBR1 encodes the amino-end-recognizing (E3) enzyme, and the $u b r 1$ null mutant is unable to degrade $X-\beta$-galactosidase bearing any of the destabilizing residues $(X)$ at the amino terminus. Sporulation is somewhat defective in the $u b r 1 \mathrm{mu}$ tant, and growth rate is slightly retarded (Bartel et al. 1990). UBR1-dependent protein degradation is inactive in the rad6 null mutant, indicating that RAD6 interacts with UBR1 in mediating multiubiquitination and degradation of substrates with destabilizing amino termini (Dohmen et al. 1991). In rabbit reticulocytes, only the $\mathrm{E} 2_{14 \mathrm{~K}}$ enzyme has been found to catalyze the E3-dependent multiubiquitination and degradation of amino-end rule substrates (Pickart and Rose 1985; Pickart and Vella 1988). Recently, this protein has been shown to be identical in sequence to the human RAD6 homolog HHR6B (Wing et al. 1992).

The structure and function of $R A D 6$ have been highly conserved during eukaryotic evolution. RAD6 is a single-copy gene in $S$. cerevisiae, Schizosaccharomyces pombe, and Drosophila melanogaster but is duplicated in human, and the two human homologs share $95 \%$ identical amino acid residues (Koken et al. 1991b). The acidic tail is found only in the $S$. cerevisiae protein; otherwise, the various homologs share a high degree of sequence identity. Genetic studies with the RAD6 homolog $r h p 6^{+}$in $S$. pombe indicate that $r h p 6^{+}$resembles RAD6 in its roles in DNA repair, mutagenesis, and sporulation. Furthermore, $S$. cerevisiae and $S$. pombe genes can substitute functionally for one another (Reynolds et al. 1990). The Drosophila and human genes also complement the DNA repair and mutagenesis defects of the $S$. cerevisiae rad6 $\Delta$ mutant (Koken et al. 199la,b).

Among the RAD6 homologs, the amino-terminal sequence has remained almost invariant. Because this conservation does not extend to other ubiquitin-conjugating enzymes, a role of this sequence in RAD6-specific functions is implicated. To delineate the role of this sequence, we have examined the effects of an amino terminal deletion mutation on various RAD6-dependent functions. We find that this mutation inactivates the amino-end rule-dependent protein degradation pathway and engenders defective sporulation and a reduction in the proficiency of DNA repair.

\section{Results}

\section{$R A D 6$ is concentrated in the nucleus}

We examined the location of RAD6 in yeast cells by indirect immunofluorescence, using affinity-purified antibodies directed against the rad6-149 protein, which is deleted for the entire acidic tail region of 23 residues. This antibody shows a very high degree of specificity toward the globular domain of RAD6. We found that RAD6 is concentrated in the nucleus, its location coinciding with the nuclear stain DAPI (Fig. 1A,B). However, some RAD6 also appears to be present in the cytoplasm. In contrast, in the rad $6 \Delta$ strain, no cross-reactivity was observed over the entire cell (Fig. 1C,D).

\section{Mutagenesis of the highly conserved amino terminus of RAD6 protein}

The amino terminus of RAD6 represents the most highly conserved segment in the protein. In this region, the first 15 residues are identical among RAD6 and its homologs, with the exception of a single difference in $S$. pombe (Fig. 2A). This sequence conservation, however, does not extend to other ubiquitin-conjugating enzymes (Fig. 2B), suggesting an involvement of the amino-terminal region in RAD6-specific functions. To examine the role of this sequence, we mutated the translation initiating ATG codon to AAG, so that translation of the mutant protein would initiate from the next methionine codon at position 10. To examine the intracellular expression of the resulting rad6 $_{\Delta 1-9}$ mutant allele, we cloned it into low-copy and multicopy yeast vectors, generating plasmids pR68 and pR64, respectively. In these plasmids, the mutant allele is fused to the normal $R A D 6$ promoter. We also fused the $r a d 6_{\Delta 1-9}$ allele to the $S$. cerevisiae highly expressed and constitutive $A D C 1$
A

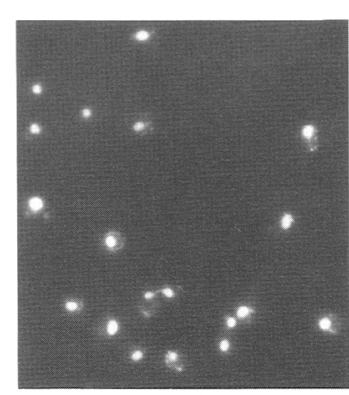

C

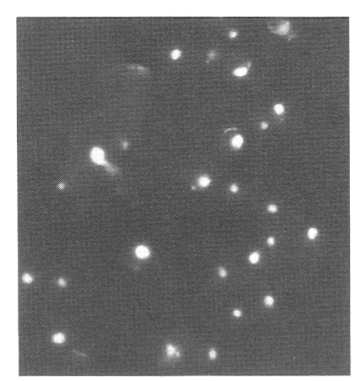

B
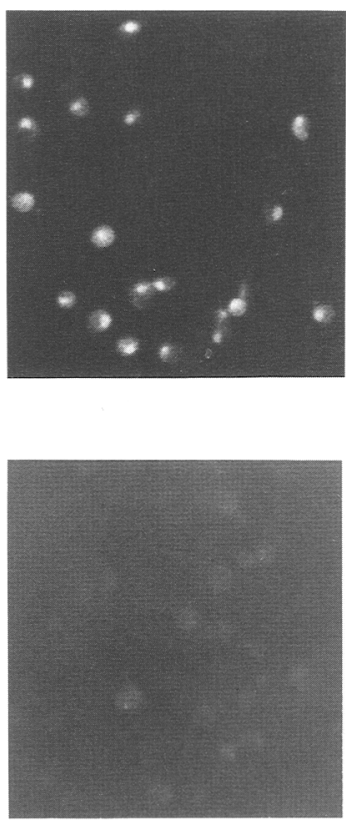

Figure 1. Nuclear localization of RAD6. Isogenic $R A D^{+}$ (LP3041-6D) and rad6A (EMY1) strains were fixed, incubated with affinity-purified anti rad6-149 antibodies, and stained with FITC (Sigma)-conjugated goat anti-rabbit IgG and with DAPI. (A) RAD6 cells visualized for DAPI and $(B)$ for FITC fluorescence. $C$ and $D$ are the same as $A$ and $B$, respectively, except that rad $6 \Delta$ cells were used. 
(A)

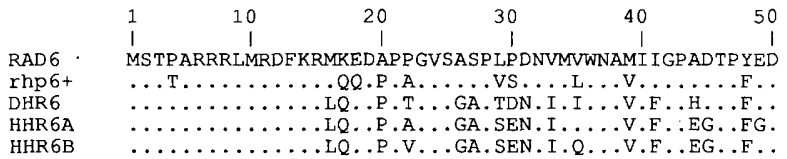

(B)

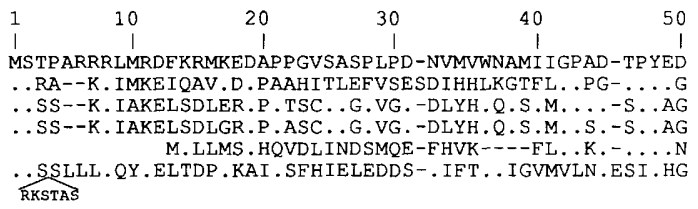

Figure 2. The amino-terminal sequence of the RAD6 protein is highly conserved among its homologs from different species, but not among other $S$. cerevisiae ubiquitin-conjugating enzymes. $(A)$ The amino-terminal 50 residues in various RAD6 homologs: S. cerevisiae RAD6 (Reynolds et al. 1985); S. pombe rhp6 $^{+}$(Reynolds et al. 1990); D. melanogaster DHR6 (Koken et al. 1991a); and human HHR6A and HHR6B (Koken et al. 1991b). $(B)$ Comparison of the first 50 residues of RAD6 protein to other ubiquitin-conjugating enzymes from $S$. cerevisiae: UBC1 (Seufert et al. 1990); UBC4 and UBC5 (Seufert and Jentsch 1990); UBC8 (Qin et al. 1991); and CDC34 (Goebl et al. 1988). Dots indicate identity to the RAD6 protein; dashes indicate gaps introduced in the protein sequence for optimal alignment. The numbers above the RAD6 sequence refer to the amino acid residue of RAD6. In UBC8, the first methionine residue occurs at a position corresponding to residue 13 of RAD6.

promoter in a multicopy vector, yielding plasmid pR661. These $r a d 6_{\Delta 1-9}$ plasmids were introduced into the rad64 strain EMY1, and the intracellular levels of mutant proteins were determined by Western immunoblot analysis. The $r a d \sigma_{\Delta 1-9}$ allele encodes a shorter protein of approximately the size expected (Fig. 3). The mutant protein was barely detectable in rad $6 \Delta$ cells carrying plasmid pR68, whereas the level of protein in cells carrying the multicopy plasmid pR64 was approximately fourfold lower than wild-type RAD6 levels. An increase of $\sim 50$ fold occurred in cells carrying the $A D C 1:$ :ad6 $_{\Delta 1-9}$ plasmid pR661 over the level of protein produced by pR64. Thus, the level of rad $_{\Delta 1-9}$ protein in rad $6 \Delta$ cells harboring pR661 is $>10$-fold higher than the level of RAD6 protein in wild-type cells.

The rad6 $_{\Delta 1-9}$ protein localizes to the nucleus

The amino terminus of RAD6 contains a high proportion of basic amino acids (see Fig. 2), and the sequence MSTPARRRL fits the common features of nuclear-targeting signals in that it is a short sequence rich in basic residues (Dingwall and Laskey 1991). To determine whether the amino terminus of RAD6 is necessary for nuclear targeting, we examined the cellular location of the $\mathrm{rad}_{\Delta 1-9}$ protein in the rad64 strain EMY1 harboring plasmid pR64. The results in Figure 4 show that the mutant protein is also located in the nucleus.

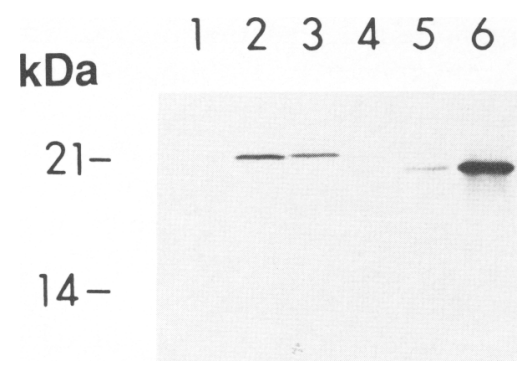

Figure 3. Western analysis of cell extracts. Isogenic $R A D^{+}$ strain (LP3041-6D) and rad6 (EMY1) strain carrying the RAD6 or the rad $_{\Delta 1-9}$ plasmid were disrupted by alternate freezing and boiling of the cells. The resulting supernatant following centrifugation was electrophoresed in a $15 \%$ polyacrylamide-SDS gel, transferred to nitrocellulose, probed with affinity-purified antirad6-149 antibodies, and developed by the indirect peroxidase procedure. Equal amounts of cell extract $\left(1 \times 10^{7}\right.$ cells $)$ were loaded for each sample. (Lane 1) rad6 strain; (lane 2) $R A D^{+}$ strain; (lane 3) rad6 $\Delta$ strain carrying the RAD6 gene on a lowcopy plasmid (pR67); (lanes 4-6) rad64 strain carrying the rad6 $_{\Delta 1-9}$ gene on a low-copy plasmid (pR68), multicopy plasmid (pR64), and multicopy ADC1 promoter fusion plasmid (pR661), respectively.

The $\operatorname{rad}_{\Delta 1-9}$ mutation confers a defect in sporulation and reduces the efficiency of DNA repair and growth rate

To determine the effects of the rad6 $6_{\Delta 1-9}$ mutation on various RAD6 functions, we examined UV survival, UV mutagenesis, sporulation, and growth rate of the rad64 strain harboring the $A D C 1::$ rad6 $_{\Delta 1-9}$ plasmid pR661. The rad $6 \Delta$ strain is extremely sensitive to UV light; for example, a $10^{4}$-fold reduction occurs in UV survival at 10 $\mathrm{J} / \mathrm{m}^{2}$. Introduction of pR661 into the rad64 strain increased the UV survival by $>100$-fold, suggesting that the RAD6 amino terminus affects the proficiency of DNA repair (Fig. 5). To determine the effect of the rad $_{\Delta 1-9}$ mutation on UV mutagenesis, we examined the
A

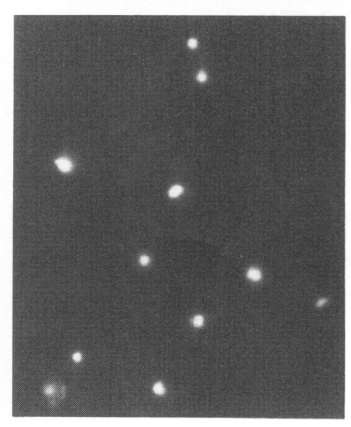

B

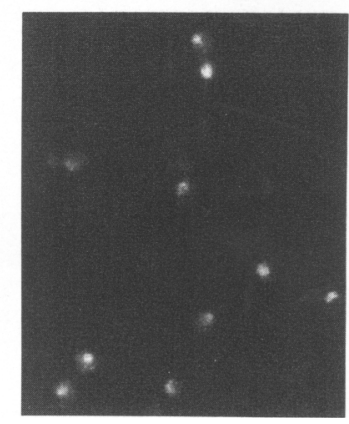

Figure 4. Nuclear location of the $\mathrm{rad}_{\Delta 1-9}$ protein. rad $6 \Delta$ strain EMY1 carrying the rad6 ${ }_{\Delta 1-9}$ gene on the multicopy plasmid pR64 was examined by indirect immunoflorescence as described in the legend to Fig. 1. DAPI $(A)$ and FITC $(B)$ fluorescence shows the location of the nucleus and the rad6 $6_{\Delta 1-9}$ mutant protein, respectively. 


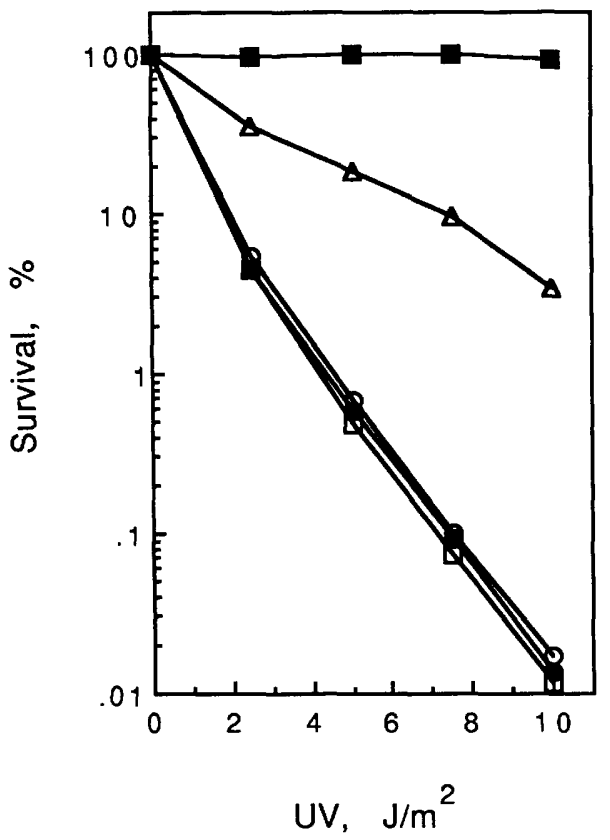

Figure 5. Survival after UV irradiation of rad $6 \Delta$ strain EMY8 and the isogenic rad $6 \Delta$ rad18 18 strain JWY1 19 carrying different plasmids. Strains were grown on media for maintaining selection of the plasmids. (口) $R A D^{+}$strain $839 ;(\square)$ rad6 6 + vector

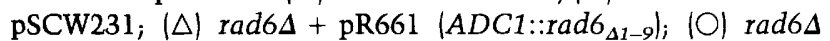

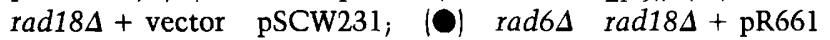
$\left(A D C 1:\right.$ :rad6 $\left._{\Delta 1-9}\right)$.

rate of UV-induced reversion of a met14 mutation. Whereas no UV mutagenesis occurs in the rad $6 \Delta$ strain, introduction of plasmid pR661 restored UV mutagenesis to a rate 5- to 10-fold higher than in the wild-type strain (Table 1).

The RAD6 epistasis group of DNA repair genes in $S$. cerevisiae consists of RAD18, REV1, REV3, and other genes (for review, see Prakash et al. 1990). RAD6 is the only gene in this group that is required both for postreplication repair and damage-induced mutagenesis. The rad18 mutant resembles rad6 in the level of UV sensitivity and in deficiency in postreplication repair but differs from rad6 in being proficient in UV mutagenesis.

Table 1. Effect of the rad6 ${ }_{\Delta 1-9}$ mutation on UV-induced reversion of met 14

\begin{tabular}{|c|c|c|c|}
\hline \multicolumn{4}{|c|}{$\begin{array}{c}\text { met }^{+} \text {revertants } \\
\text { EMY7 per } 10^{7} \text { survivors in isogenic rad } 6 \Delta \text { strain } \\
\text { EMY carrying different plasmids }\end{array}$} \\
\hline $\begin{array}{l}\text { UV dose } \\
\left(\mathrm{Jm}^{-2}\right)\end{array}$ & $\begin{array}{l}\text { pSCW231 } \\
\text { (rad6 } 6)\end{array}$ & $\begin{array}{l}\text { pR67 } \\
|R A D 6|\end{array}$ & $\begin{array}{l}\text { pRR661 } \\
\left(\text { rad6 }_{\Delta 1-9}\right)\end{array}$ \\
\hline 0 & 0.0 & 0.3 & 0.9 \\
\hline 2 & 0.0 & 13.0 & 83.0 \\
\hline 4 & 0.0 & 48.0 & 262.0 \\
\hline 6 & 0.0 & 65.0 & 618.0 \\
\hline
\end{tabular}

${ }^{a}$ Values represent the average of at least three independent experiments.
Although the rev1 and rev3 mutants are defective in UV mutagenesis, they are only marginally UV sensitive, suggesting that mutagenic bypass of DNA damage constitutes a minor DNA repair pathway in yeast. Thus, RAD6 functions with RAD18 in error-free DNA repair and with REV1 and REV3 in mutagenic bypass. The higher level of UV resistance of the rad6 $6_{\Delta 1-9}$ mutant over that of the rad $6 \Delta$ strain could arise from partial inactivation of the $R A D 18$-dependent DNA repair pathway in the rad6 $_{\Delta 1-9}$ strain. Alternatively, although the RAD18 pathway could be completely inactive in the rad6 $6_{\Delta 1-9}$ mutant, increased UV resistance might result from a more efficient processing of DNA damage by mutagenic bypass. In the latter case, we would expect the UV resistance of rad $6 \Delta$ rad18 18 cells harboring plasmid pR661 to be similar to that of the rad6 $\Delta$ strain carrying pR661. Therefore, to distinguish between these possibilities, we examined the UV sensitivity of a rad $6 \Delta$ rad18 $\Delta$ mutant strain with or without the plasmid pR661. Because we found no increase in the UV resistance of rad6 $\mathrm{rad18 \Delta}$ cells upon introduction of plasmid pR661 (Fig. 5), we infer partial inactivation of the RAD18 pathway rather than a more efficient mutagenic bypass to be the likely reason for the observed level of UV sensitivity in the rad6 $_{\Delta 1-9}$ mutant.

The rad $_{\Delta 1-9}$ mutation renders cells sporulation defective, as no sporulation occurred in the rad $6 \Delta / \mathrm{rad} 6 \Delta \mathrm{dip}-$ loid strain carrying plasmid pR661 (Table 2). Western immunoblotting of cell extracts at various times during sporulation indicated that the level of $\mathrm{rad}_{\Delta 1-9}$ protein stays $\sim 10$-fold higher than the level of RAD6 protein in wild-type cells (data not shown). Therefore, the failure of rad6 6 /rad $6 \Delta$ cells harboring pR661 to sporulate is not the result of reduced levels of mutant protein under sporulation conditions. The rad $_{\Delta 1-9}$ mutation also affects growth rate adversely (Table 3 ); the growth rate of the mutant was intermediate between that of the wildtype and rad6 null strains. Growth rate was not affected by the rad6-149 mutation. This mutation renders cells sporulation defective, but DNA repair and mutagenesis remain unaffected (Morrison et al. 1988).

\section{Defective amino-end-dependent protein degradation in} the rad $6_{\Delta 1-9}$ mutant

The RAD6 gene is specifically required for ubiquitination and subsequent degradation of proteins dependent on the identity of the amino terminal residue (Dohmen

Table 2. Sporulation of $\mathrm{rad} 6 \Delta / \mathrm{rad} 6 \Delta$ strain carrying different plasmids

\begin{tabular}{lllr}
\hline Strain & Plasmid & Gene & $\begin{array}{l}\text { Sporulation } \\
(\%)^{\mathbf{a}}\end{array}$ \\
\hline EMY28 & pSCW231 & rad64 & 0 \\
EMY26 & pR67 & RAD6 & 35 \\
EMY28 & pR661 & rad6 $_{\Delta 1-9}$ & 0
\end{tabular}

${ }^{\text {a Based on a count of }>1000 \text { cells for each strain. Strains EMY26 }}$ and EMY28 are isogenic. 
Watkins et al.

Table 3. Growth rates of rad6 6 strain EMY1 carrying the RAD6 or mutant rad6 gene on a plasmid

\begin{tabular}{llc}
\hline Plasmid & Genotype & Doubling time $^{\mathrm{a}}(\mathrm{hr}) \pm$ S.D. \\
\hline pR67 & RAD6 & $1.54 \pm 0.15$ \\
pSCW231 & rad6 & $2.70 \pm 0.07$ \\
pR661 & rad6 $_{\Delta 1-9}$ & $2.12 \pm 0.14$ \\
pR615 & rad6-149 & $1.51 \pm 0.06$ \\
\hline
\end{tabular}

${ }^{a}$ Average of at least three independent experiments carried out at $30^{\circ} \mathrm{C}$.

et al. 1991; Sung et al. 1991). In this role, RAD6 interacts with the $U B R 1$-encoded amino-end-recognizing protein. To examine the effect of the $\mathrm{radb}_{\Delta 1_{-9}}$ mutation on degradation of amino-end rule substrates, as well as that of rad6-153 and rad6-149 mutations deleted for the sequence encoding the last 19 or 23 amino acids of the acidic tail, respectively, we used plasmids (KEP268, KEP269, KEP270; Table 4) in which the Escherichia coli $\beta$-galactosidase gene bearing different amino-terminal codons is fused to the ubiquitin gene placed under the control of the GAL1O promoter (Bachmair et al. 1986). Expression of $\mathrm{Ub}-X-\beta-\mathrm{Gal}$ plasmids in yeast results in the cleavage of ubiquitin, yielding the $X-\beta$-Gal protein, where $X$ denotes the amino-terminal residue. $U b-X-\beta$ Gal plasmids encoding Met, a stabilizing residue, $\mathrm{Arg}$, a type I destabilizing residue, or Leu, a type II destabilizing residue at the amino terminus, were introduced into isogenic $R A D^{+}$and rad6 6 strains. The rad $6 \Delta$ strains, each harboring a different $\mathrm{Ub}-X-\beta$-Gal plasmid, were then transformed with a plasmid bearing either the rad6 $6_{\Delta 1-9}$ (pR661), the rad6-149 (pR615), or the rad6-153 (pR616) mutant allele, and the stability of $X-\beta-$ Gal proteins determined by measuring the steady-state levels of $\beta$-galactosidase, and by pulse-chase experiments.

In the $R A D^{+}$strain, the steady-state level of Met- $\beta$ Gal was much higher than that of Arg- $\beta-$ Gal or Leu- $\beta$ Gal, whereas in the rad6 6 strain, Arg- $\beta$-Gal and Leu- $\beta$ Gal increased to levels nearly equal to that of the stable

Table 4. Plasmids used in this study

\begin{tabular}{|c|c|}
\hline Plasmid & Gene, vector, and nutritional marker \\
\hline $\mathrm{pR} 64$ & $\operatorname{rad}_{\Delta 1-9}$ gene in $2 \mu$ vector (URA3) \\
\hline $\mathrm{pR} 67$ & $R A D 6$ gene in CEN vector (URA3) \\
\hline pR68 & rad $_{\Delta 1-9}$ gene in CEN vector (URA3) \\
\hline pR615 & rad6-149 gene in CEN vector (URA3) \\
\hline $\mathrm{pR} 616$ & rad6-153 gene in CEN vector (URA3) \\
\hline pR661 & $\begin{array}{l}A D C 1 \text { promoter::rad6 } \\
\text { vector }(\text { TRP1) }\end{array}$ \\
\hline pSCW231 & $A D C 1$ promoter in $2 \mu$ vector (TRP1) \\
\hline KEP268 & $\begin{array}{l}\text { GAL10 promoter::Ub-Met- } \beta-\text { Gal in } 2 \mu \\
\text { vector (URA3) }\end{array}$ \\
\hline KEP269 & $\begin{array}{l}\text { GAL10 promoter::Ub-Arg- } \beta-\text { Gal in } 2 \mu \\
\text { vector (URA3) }\end{array}$ \\
\hline KEP270 & $\begin{array}{l}\text { GAL10 promoter::Ub-Leu- } \beta-\text { Gal in } 2 \mu \\
\text { vector (URA3) }\end{array}$ \\
\hline pSOB44 & $A D C 1$ promoter: $U B R 1 / h a$ in $2 \mu$ vector (TRP1) \\
\hline
\end{tabular}

Met- $\beta$-Gal (Fig. 6). The levels of Arg- $\beta$-Gal and Leu- $\beta$ Gal in the rad6 $6_{\Delta 1-9}$ mutant resembled those in the rad64 strain, suggesting that the RAD6-mediated amino-end rule pathway is defective in the $\mathrm{rad}_{\Delta 1-9}$ mutant. In contrast, cells carrying the rad6-153 gene displayed normal activity, whereas the proficiency of degradation was reduced in the rad6-149 mutant. These findings are in agreement with our previous in vitro studies, indicating that rad6-153 protein was as efficient as RAD6 in E3dependent protein ubiquitination and subsequent degradation, whereas the rad6-149 protein showed reduced levels of activity (Sung et al. 1991).

Pulse-chase experiments done to verify and extend the results obtained from colorimetric assays of $\beta$-gal levels are shown in Figure 7. In $R A D^{+}$cells, during the 15-min chase period, Met $-\beta-\mathrm{Gal}$ was stable but Arg- $\beta$-Gal and Leu- $\beta$-Gal proteins decayed with an approximate halflife of $3 \mathrm{~min}$ and $5 \mathrm{~min}$, respectively. Multiubiquitinated species of Arg- $\beta$-Gal and Leu- $\beta$-Gal were evident, particularly in the 0 -min sample, and these proteins also generated a $\beta$-Gal cleavage product of $\sim 90 \mathrm{kD}$. For the stable Met- $\beta$-Gal protein, there was no evidence of formation of either the higher molecular weight species representing ubiquitinated $\beta-\mathrm{Gal}$ or of the $90-\mathrm{kD}$ product. In contrast, in the rad $6 \Delta$ and rad6 ${ }_{\Delta 1-9}$ strains, $\mathrm{Arg}_{-}$ $\beta$-Gal and Leu- $\beta$-Gal proteins became stabilized like the

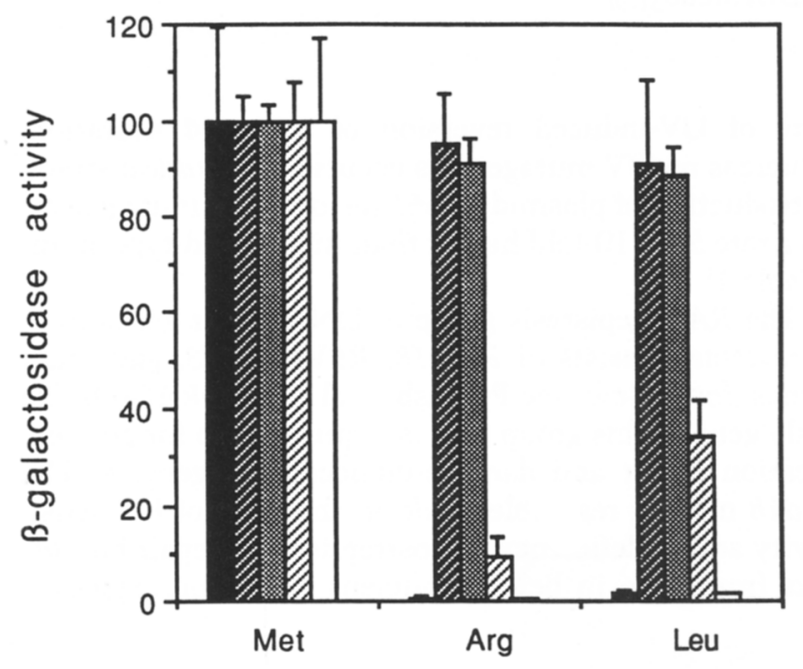

\section{Amino terminal residue $X$ in $U b-X-B g a$}

Figure 6. rad $_{\Delta 1-9}$ mutant is defective in the amino-end rule degradation pathway in vivo. Levels of $\beta$-Gal activity in $R A D^{+}$ and various mutant rad6 strains expressing either Ub-Met- $\beta$ $\mathrm{Gal}, \mathrm{Ub}-\mathrm{Arg}-\beta-\mathrm{Gal}$, or Ub-Leu- $\beta$-Gal. Cells were grown to a density of $1 \times 10^{7}$ cells $/ \mathrm{ml}$ in selection medium containing $2 \%$ galactose as the sole carbon source and assayed for $\beta$-gal activity as described in Materials and methods. Values shown represent the average of at least three independent experiments. The levels of Arg- $\beta$-Gal and Leu- $\beta$-Gal in each strain were normalized to the Met- $\beta$-Gal activity (set at $100 \%$ ) in that particular strain. Standard deviation is shown above each bar. (Solid bar) $R A D^{+}$; (dark hatched bar) rad6 $\Delta_{\text {; }}$ (crosshatched bar) rad6 ${ }_{\Delta 1-9}$; (light hatched bar) rad6-149; (open bar) rad6-153. 


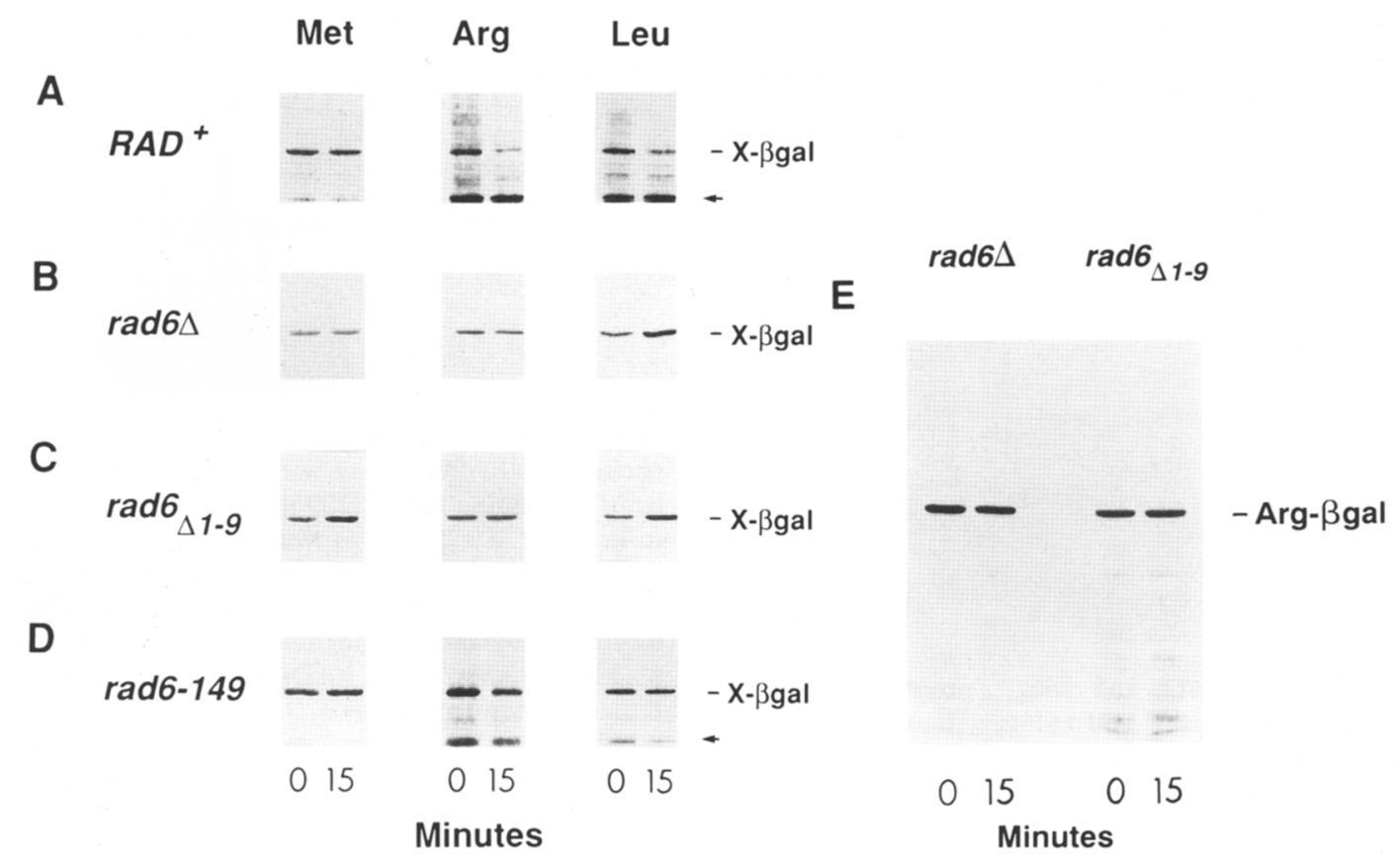

Figure 7. Pulse-chase analysis of $X-\beta-\mathrm{Gal}$ in $R A D^{+}$and various rad6 mutants. Cultures of exponentially growing cells $10.5 \times 10^{7}$ to $1.0 \times 10^{7}$ cells $/ \mathrm{ml}$ ) expressing either Ub-Met- $\beta-\mathrm{Gal}, \mathrm{Ub}-\mathrm{Arg}-\beta-\mathrm{Gal}$, or Ub-Leu- $\beta$-Gal were labeled for 5 min with $\left[{ }^{35} \mathrm{~S}\right] \mathrm{methionine}$ at $30^{\circ} \mathrm{C}(0 \mathrm{~min})$, followed by a chase at $30^{\circ} \mathrm{C}$ in the presence of cycloheximide and unlabeled methionine for $15 \mathrm{~min}(15 \mathrm{~min}) . \beta$-Gal was immunoprecipitated from the cells and subjected to electrophoresis and fluorography as described in Materials and methods. $(A-D)$ The $X-\beta$-Gal band is indicated, and the position of the $\sim 90-\mathrm{kD}$ long-lived $\beta$-Gal cleavage product is marked by an arrow. Higher molecular weight species representing multiubiquitinated forms of Arg- $\beta$-Gal and Leu- $\beta$-Gal appear in the $R A D^{+}$strain and, to a lesser extent, in the rad6-149 mutant. $(E)$ To show unequivocally the absence of multiubiquitination and degradation of Arg- $\beta-G a l$ in the rad $6 \Delta$ and rad $_{\Delta 1-9}$ strains, the Arg- $\beta-$ Gal gels in $B$ and $C$ were exposed for a longer period.

Met- $\beta$-Gal protein, and we did not observe any multiubiquitinated species or $90-\mathrm{kD}$ cleavage product in either mutant. Degradation of Arg- $\beta$-Gal and Leu- $\beta$-Gal proteins occurred in the rad6-149 mutant but at a slower rate than in the $R A D^{+}$strain; the half-life of Arg- $\beta-G a l$ was increased to $\sim 12 \mathrm{~min}$, and that of Leu- $\beta-$ Gal was increased to $\sim 50 \mathrm{~min}$. Thus, our studies indicate that the rad6 $6_{\Delta 1-9}$ mutant lacks the ability to function in the amino-end rule protein degradation pathway, whereas the efficiency of this pathway is reduced in the rad6-149 mutant.

The rad6 $6_{\Delta 1-9}$ protein is defective in E-3-dependent protein degradation in vitro

RAD6-dependent multiubiquitination and degradation of substrates bearing destabilizing amino-terminal residues can be examined in vitro using the proteolytic system derived from rabbit reticulocytes (Sung et al. 1991); the E3 component of this cell-free system is functionally equivalent to the UBRl gene product of yeast. To assess the ability of the $\mathrm{rad}_{\Delta 1-9}$ mutant protein to function with E3 in amino-end-dependent protein degradation, we purified the rad6 ${ }_{\Delta 1-9}$ protein to near homogeneity (Fig. 8) from extract of the rad6A strain EMY8 harboring the plasmid pR661 (ADC1::rad6 $\left.{ }_{\Delta 1-9}\right)$ by a combination of four-column chromatographic steps (see Materials and methods).

The RAD6 and rad6 $6_{\Delta 1-9}$ proteins were tested for their ability to cooperate with E3 in the degradation of ${ }^{125} \mathrm{I}$ labeled $\beta$-lactoglobulin, which has leucine at its amino terminus, a destabilizing amino-terminal residue in both rabbit reticulocytes and yeast. Consistent with our previous findings (Sung et al. 1991), RAD6 promoted the degradation of $\beta$-lactoglobulin in the proteolytic system, showing a strict requirement for E3, ubiquitin, and the ubiquitin-specific protease (Table 5). In contrast, the rad6 $_{\Delta 1-9}$ protein, even in an amount fivefold higher than RAD6, was totally ineffective in protein degradation ( Table 5). We also examined the formation of ubiquitinated $\beta$-lactoglobulin by subjecting reaction mixtures to SDSPAGE and autoradiography, as described previously (Sung et al. 1991; see Materials and methods). In contrast to the RAD6 protein, which catalyzes the multiubiquitination of $\beta$-lactoglobulin (Fig. 9, lane 3), the $\mathrm{rad6}_{\Delta 1-9}$ protein did not function in this reaction (Fig. 9, lanes $4,5)$.

Conceivably, the failure of $\operatorname{rad}_{\Delta 1-9}$ protein to mediate multiubiquitination and degradation of $\beta$-lactoglobulin could occur upstream of E3 interaction, that is, in thioester formation with ubiquitin, a reaction catalyzed by the ubiquitin-activating enzyme $\mathrm{E} 1$. To eliminate this possibility, we examined the formation of ubiquitin 


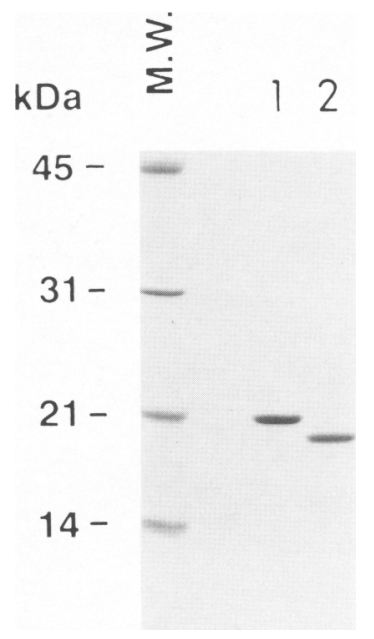

Figure 8. SDS-PAGE of RAD6 and $\mathrm{rad}_{\Delta 1-9}$ proteins. One microgram each of RAD6 (lane 1) and $\operatorname{rad}_{\Delta 1-9}$ (lane 2) proteins, purified as described in Materials and methods, was electrophoresed in a $12.5 \%$ polyacrylamide-SDS gel and stained with Coomassie blue.

thioester (Sung et al. 1988) with the RAD6 and rad6 ${ }_{\Delta 1-9}$ proteins, using the same El preparation as we used in the protein-degradation experiments. We found that the rad6 $_{\Delta 1-9}$ protein readily forms thioester with ubiquitin, indicating that the mutant protein retains the ability to interact with El and ubiquitin (Fig. 10).

\section{Defective physical interaction of the rad6 $6_{\Delta 1-9}$ protein with the UBR1 gene product}

The results presented above establish that the ad $_{\Delta 1-9}$ mutation inactivates the amino-end rule function of RAD6 protein. Using methodology similar to that employed by Dohmen et al. (1991) in demonstrating physical interaction between RAD6 and UBRl proteins, we examined whether the rad6 $_{\Delta 1-9}$ protein interacts with UBR1.

The rad $6 \Delta u b r 1 \Delta$ yeast strain BBY 68 was transformed

Table 5. rad6 $_{\Delta 1-9}$ protein is ineffective in E3-dependent protein degradation

\begin{tabular}{llcc}
\hline E2 enzyme & $\begin{array}{l}\text { Reaction } \\
\text { mix }\end{array}$ & $\begin{array}{l}\text { Degradation } \\
(\%)\end{array}$ & $\begin{array}{l}\text { Activity relative } \\
\text { to RAD6 }(\%)\end{array}$ \\
\hline RAD6 $^{\mathrm{a}}$ & complete & 21.5 & 100 \\
RAD6 $^{\mathrm{a}}$ & - E3 & 0.4 & 2 \\
RAD6 $^{\mathrm{a}}$ & - ubiquitin & 0 & 0 \\
RAD6 $^{\mathrm{a}}$ & - protease & 0 & 0 \\
rad6 $_{\Delta 1-9}{ }^{\mathrm{a}}$ & complete & 0 & 0 \\
rad6 $_{\Delta 1-9}$ & complete & 0 & 0 \\
\hline
\end{tabular}

RAD6 and rad6 $6_{\Delta 1-9}$ proteins were examined for the ability to mediate E3 dependent degradation of ${ }^{125}$ I-labeled $\beta$-lactoglobulin as described in Materials and methods. The concentration of $\mathrm{E} 2$ in the assays was $200 \mathrm{nM}^{\mathrm{a}}$ or $1 \mu \mathrm{M}^{\mathrm{b}}$.

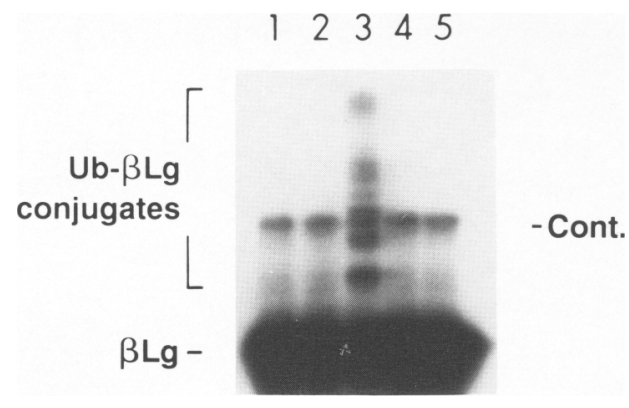

Figure 9. E3-dependent multiubiquitination of $\beta$-lactoglobulin occurs with RAD6 but not with rad6 $_{\Delta 1-9}$ protein. Reaction mixtures containing RAD6 (200 nM; lanes 1-3) or rad6 ${ }_{\Delta 1-9}(200 \mathrm{nM}$ in lane $4 ; 1 \mu \mathrm{M}$ in lane 5) were assembled as described in $\mathrm{Ma}$ terials and methods, incubated at $37^{\circ} \mathrm{C}$ for $20 \mathrm{~min}$, and subjected to electrophoresis in a $12.5 \%$ polyacrylamide-SDS gel, followed by autoradiography of the dried gel. (Lane 1) With RAD6 but no ubiquitin; (lane 2) with RAD6 but no E3; (lane 3) with RAD6, E3, and ubiquitin; (lanes 4,5) rad6 ${ }_{\Delta 1-9}$ with E3 and ubiquitin. $(\beta \mathrm{Lg})^{125}$ I-labeled $\beta$-lactoglobulin; (Cont.) contaminant in the $\beta$-lactoglobulin preparation; (Ub- $\beta \mathrm{Lg}$ ) ubiquitin conjugates of $\beta$-lactoglobulin in lane 3.

with the plasmid pSOB44 $(A D C 1:: U B R 1 / h a)$, a highcopy plasmid containing the $U B R 1$ gene carrying a carboxy-terminal 9-residue extension [derived from hemagglutinin (ha) of influenza virus] under the control of the ADC1 promoter (Dohmen et al. 1991). Cell extract containing the UBR1/ha protein was mixed with the purified RAD6 or rad6 $6_{\Delta 1-9}$ protein and, after incubation, subjected to immunoprecipitation with protein A-agarose beads bearing affinity-purified anti-RAD6 antibodies. After washing, proteins from immunoprecipitates were

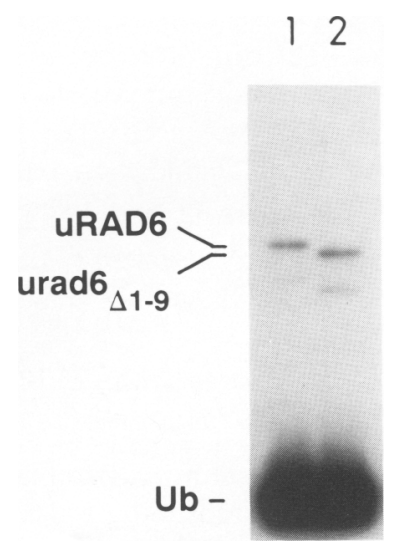

Figure 10. $\operatorname{rad}_{\Delta 1-9}$ protein forms thioester conjugate with ubiquitin. Formation of ubiquitin thioester with RAD6 (lane 1) or $\operatorname{rad6}_{\Delta 1-9}$ (lane 2) protein was carried out as described in Materials and methods. The ubiquitin thioester conjugates (uRAD6 and urad6 ${ }_{\Delta 1-9}$ ) were readily disrupted by treatment with 2-mercaptoethanol (not shown). The minor band below uRAD6 and urad6 $6_{\Delta 1-9}$ is a proteolytic product generated by a contaminating protease in the ubiquitin preparation. (Ub) ${ }^{125} \mathrm{I}$ labeled ubiquitin. 
eluted by treatment with $2 \%$ SDS, and the eluates analyzed by immunoblotting (Fig. 11A,B) with either antiRAD6 antibodies (Sung et al. 1988) or the monoclonal antibody 12CA5 specific for the ha epitope (Field et al. 1988 ) in UBR1/ha. In agreement with the result of Dohmen et al. (1991), we found that RAD6 forms a physical complex with the $226-\mathrm{kD}$ UBR 1 /ha protein, as indicated by coprecipitation of the two proteins (Fig.11A,B, lanes 2). The rad6 ${ }_{\Delta 1-9}$ protein, however, did not coprecipitate the UBR1/ha protein (Fig. 11A,B, lanes 3), indicating a defect in interaction with the UBRl protein.

\section{Discussion}

The amino terminus of RAD6 is extremely conserved, where the first 15 residues are almost invariant in RAD6 and its homologs from yeast to human. Because conservation of this domain is specific to RAD6 and does not extend to the other ubiquitin-conjugating enzymes, we expected this sequence to be required for interactions with specific protein components that mediate RAD6dependent functions, rather than in interactions with proteins in the ubiquitin-conjugating pathway, such as the ubiquitin-activating enzyme El or ubiquitin itself. RAD6 differs from the other ubiquitin-conjugating enzymes in its requirement in DNA repair, mutagenesis, and sporulation and in its capacity to catalyze E3-dependent multiubiquitination of amino-end rule substrates. These functions of RAD6 are also shared by its homologs from higher eukaryotes, as these homologs can complement the DNA repair and mutagenesis defects of the $S$.

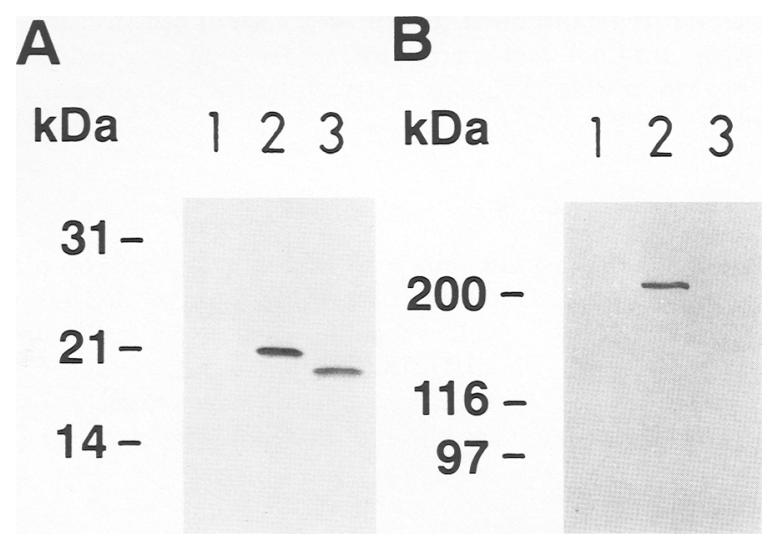

Figure 11. rad6 $6_{\Delta 1-9}$ mutation disrupts physical interaction with the UBR1 protein. Extract from strain BBY68 carrying the plasmid pSOB44 expressing the UBR1/ha protein (lane 1) was incubated with $1 \mu \mathrm{g}$ of RAD6 (lane 2) or $1 \mu \mathrm{g}$ of rad6 $_{\Delta 1-9}$ (lane 3) protein and then subjected to immunoprecipitation using protein A-agarose beads bearing affinity-purified anti-RAD6 antibodies. Proteins in immunoprecipitates were eluted by SDS treatment, separated in $12.5 \%(A)$ and $7 \%(B)$ denaturing polyacrylamide gels, transferred onto nitrocellulose, and probed with anti-RAD6 antibodies $(A)$ and with the monoclonal antibody $12 C A 5(B)$ specific for the ha epitope in UBR1/ha. No UBR1/ha protein was coprecipitated even with $3 \mu \mathrm{g}$ of $\operatorname{rad}_{\Delta 1-9}$ protein (data not shown). cerevisiae rad6 $\Delta$ mutant (Reynolds et al. 1990; Koken et al. $1991 \mathrm{a}, \mathrm{b})$. In rabbit reticulocytes, $\mathrm{E} 2 \mathrm{1}_{14 \mathrm{~K}}$ is the only ubiquitin-conjugating enzyme that functions in E3-dependent multiubiquitination and degradation of substrates, and this protein is identical in sequence to the human RAD6 homolog HHR6B (Wing et al. 1992). To determine the role of the amino-terminal sequence, we examined the effects of a rad6 $6_{\Delta 1-9}$ mutation, in which the first 9 residues of the protein are deleted, on RAD6specific functions. We show that RAD6 is a nuclear protein and that the rad $_{\Delta 1_{-} 9}$ mutation has no adverse effect on nuclear localization. Because of the presence of basic amino acids in residues $10-15$, we examined whether these residues were responsible for nuclear entry of the rad6 $_{\Delta 1-9}$ protein. We constructed a rad6 $6_{\Delta 1-15}$ mutant allele by simultaneously changing the ATG codons at positions 1 and 10 to AAG, which results in a protein deleted for the first 15 residues. However, we found that this protein also localizes to the nucleus (data not shown).

The most interesting finding to emerge from our studies is the inability of the $\operatorname{rad}_{\Delta 1-9}$ protein to function in the amino-end-dependent protein degradation pathway in both yeast and rabbit reticulocytes. In the add $_{\Delta 1-9}$ mutant, the short-lived $\beta$-Gal proteins containing either the arginine- or the leucine-destabilizing residue at the amino terminus become metabolically stabilized, and the severity of the defect in the mutant was identical to that in the rad6 null mutant. In the proteolytic system derived from rabbit reticulocytes, we show that $\operatorname{rad}_{\Delta 1-9}$ protein has lost the ability to mediate multiubiquitination and degradation of $\beta$-lactoglobulin, which bears the destabilizing residue leucine at its amino terminus. Results from the coimmunoprecipitation experiments indicate that the defect of $\mathrm{rad}_{\Delta 1-9}$ protein in the aminoend rule function is the result of a failure to physically interact with the UBR1-encoded E3 enzyme.

The rad $_{\Delta 1-9}$ mutation has a striking effect on sporulation, as rad $6 \Delta / \mathrm{rad} 6 \Delta$ cells carrying this mutant gene do not sporulate. This mutation also lowers the proficiency of DNA repair and reduces growth rate, whereas the rate of UV mutagenesis is elevated a fewfold. Because ubiquitin-conjugating activity is essential for all RAD6 biological functions (Sung et al. 1990), the differential effects of the rad6 $6_{\Delta 1-9}$ mutation in these cellular processes very likely stem from the inability of the mutant protein to interact with specific protein components that affect these processes. Because the RAD6 amino terminus is essential for interaction with the yeast E3 enzyme encoded by the $U B R 1$ gene, we suggest that a simultaneous defect in interactions with additional E3 enzymes could underlie the phenotypic defects observed in the radb $_{\Delta 1-9}$ mutant.

Both in yeast and rabbit reticulocytes, there is evidence for the existence of multiple E3 enzymes that recognize different amino termini. A protein, E3-R, partially purified from $S$. cerevisiae vegetative cells, has been shown to mediate ubiquitination of amino-end rule substrates by RAD6 (Sharon et al. 1991). In conjunction with E3-R, RAD6 also ubiquitinates a substrate with a 
blocked amino terminus. The level of E3-R activity is not affected by the ubr1 null mutation; therefore, E3-R and UBR1 represent different proteins. In rabbit reticulocytes, in addition to E3 $\alpha$, which recognizes substrates bearing type I (basic) or type II (bulky hydrophobic) destabilizing amino termini and which specifically interacts with RAD6 (Sung et al. 1991), another protein, E3 $\beta$ has been purified that recognizes type III substrates that bear Ala, Ser, or Thr at the amino terminus (Heller and Hershko 1990). These residues are destabilizing in reticulocyte lysates but not in yeast, presumably because of the presence of E3 $\beta$ in reticulocytes. It is not known whether the rabbit RAD6 homolog $\mathrm{E}_{14 \mathrm{~K}}$ interacts with E3 $\beta$.

In addition to defective interaction with UBR1, the rad6 $6_{\Delta 1-9}$ protein could be defective in interacting with E3-R and also with other E3 proteins that might recognize determinants other than the amino terminus. A common sequence in various E3 proteins might govern their interaction with the RAD6 amino terminus. Our finding that the rad6 $6_{\Delta 1-9}$ mutant is defective in both sporulation and UBR1-mediated protein degradation is consistent with the suggestion that E3-dependent ubiquitination of substrates by RAD6 might constitute an essential protein degradation pathway in sporulation. The rad6-149 mutation also causes sporulation deficiency in S. cerevisiae (Morrison et al. 1988), indicating the requirement of the acidic tail in this process. The rad6-149 protein, however, can function in E3-dependent degradation, albeit at a slower rate. Because the acidic tail is found only in the $S$. cerevisiae RAD6 protein, its indispensability in sporulation would appear to be restricted to this species. An essential role of the RAD6 globular domain in sporulation is indicated from studies with the S. pombe rhp6 ${ }^{+}$gene. Although rhp6 ${ }^{+}$does not contain the acidic tail, it is essential for sporulation in $S$. pombe, as manifested from the inability of the rhp6 $\Delta /$ rhp6 6 mutant strain to sporulate. Moreover, the $S$. cerevisiae rad6-149 gene restores a normal level of sporula-

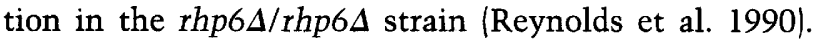
Our studies reported here indicate an involvement of the RAD6 amino terminus in this sporulation specific role of the globular domain. Because the amino-terminal sequence is almost invariant from yeast to human, we expect the sporulation/meiosis-specific role of the RAD6 amino terminus to be conserved among eukaryotes. Furthermore, if the RAD6 amino terminus interacts with related E3 proteins, then we anticipate a parallel evolutionary conservation of these E3 proteins as well.

The reduced efficiency of DNA repair in the $\mathrm{rad}_{\Delta 1-9}$ mutant could arise as a pleiotropic effect of defective E3 interactions, and decreased growth rate may be a consequence of defective repair of spontaneous DNA lesions. An association between DNA repair and growth rate is suggested from the following observations: (1) the rad6149 mutant is defective in sporulation but DNA repair and growth rate remain unaffected; (2) null mutations in the RAD18 and RAD5 genes, both members of the RAD6 epistasis group, have no effect on sporulation, but they diminish both DNA repair and growth rate (Johnson et al. 1992); and (3), the SRS2 mutation suppresses both the DNA repair and growth defects in the rad6 null mutation by channeling DNA lesions into the alternate DNA repair pathway controlled by genes in the RAD52 epistasis group (Schiestl et al. 1990). RAD6, by its E3-dependent roles, may control the levels of exopeptidases or endopeptidases which, in turn, affect the levels of DNA repair proteins. A decrease in the level of some limiting proteins, resulting from elevated peptidase levels in the $\mathrm{rad6}_{\Delta 1-9}$ mutant, might underlie the DNA repair and growth defects. Another possibility is that the RAD6 amino terminus directly interacts with DNA repair proteins. In that case, the RAD6 amino terminus would be expected to interact with E3 proteins, as well as with DNA repair proteins, by recognition of a common sequence motif. However, we have observed no evidence of any similar sequence shared among UBR1, RAD18, RAD5, and several other DNA repair proteins. We also examined the possibility that amino acids $10-15$ provide the $\mathrm{rad}_{\Delta 1-9}$ protein the residual capacity to interact with DNA repair proteins. However, we found that the UV sensitivity and growth rate, as well as UV mutagenesis, in the rad6 $6_{\Delta 1-15}$ mutant were virtually identical to that in the rad6 $6_{\Delta 1-9}$ mutant (data not shown).

In summary, we suggest that the RAD6 amino terminus is specifically involved in interactions with various E3 proteins and that E3 dependent ubiquitination of substrates is essential for sporulation and affects the proficiency of DNA repair.

\section{Materials and methods}

Strains and plasmids

S. cerevisiae strains used in this study are listed in Table 6 . Growth, minimal, and sporulation media were prepared as described (Sherman et al. 1986). A list of plasmids used is given in Table 4.

\section{Yeast transformation and other procedures}

Introduction of plasmids into yeast strains was done according to Ito et al. (1983). Determination of UV survival and UV-induced mutagenesis, as well as techniques for Western immunoblotting and affinity purification of antibodies, were as described previously (Morrison et al. 1988). Electrophoresis of proteins on SDS-polyacrylamide gels was performed according to Laemmli (1970).

\section{Construction of rad6 ${ }_{\Delta 1-9}$ plasmids}

The initiation codon of the RAD6 gene was changed from ATG to AAG by site-directed mutagenesis (Zoller and Smith 1984). The mutation was made using the oligonucleotide 5 '-TGGTGTGGACTTGACGCTTTA-3', which corresponds to the antisense DNA strand of RAD6 from positions +12 to -9 (Reynolds et al. 1985). A 613-bp EcoRI fragment containing the mutation was used to replace the wild-type RAD6 sequence in the same fragment from plasmids pTB227, pR67 (Morrison et al. 1988), and pSCW242 (Sung et al. 1990) yielding plasmids pR64, pR68, and pR661, respectively (Table 4). DNA sequence analysis of the mutant gene confirmed that only the desired change had occurred. 
Table 6. S. cerevisiae strains used

\begin{tabular}{|c|c|c|}
\hline Strain & Genotype & Source \\
\hline LP3041-6D & 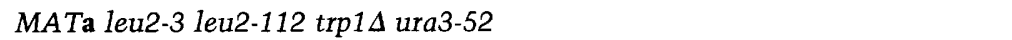 & Sung et al. (1990) \\
\hline 839 & MAT $\alpha$ ade5 his7 leu2-3 lys1 met14 pet5 ura3 & Morrison et al. $(1988)$ \\
\hline EMY1 & 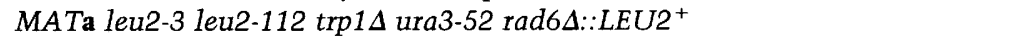 & Morrison et al. (1988) \\
\hline EMY7 & 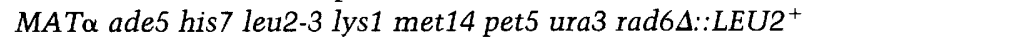 & Morrison et al. (1988) \\
\hline EMY8 & 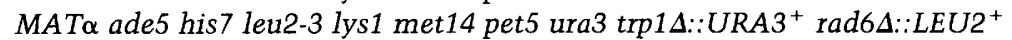 & Reynolds et al. (1990) \\
\hline YPH500 & 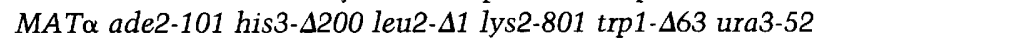 & Sikorski and Hieter (1989) \\
\hline JWY119 & 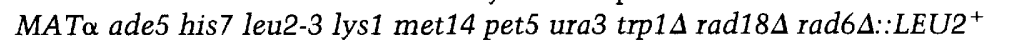 & this study \\
\hline JWY182 & 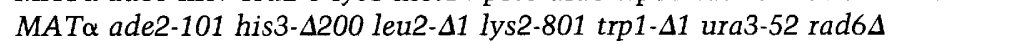 & this study \\
\hline BBY68 & 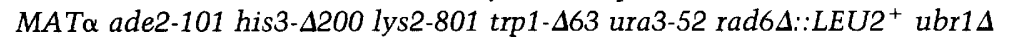 & Dohmen et al. (1991) \\
\hline EMY26 & rad $6 \Delta /$ rad6 6 (EMY1 × EMY7) & Sung et al. (1990) \\
\hline EMY28 & $\mathrm{rad} 6 \Delta / \mathrm{rad} 6 \Delta(\mathrm{EMY} 1 \times \mathrm{EMY} 8)$ & Reynolds et al. (1990) \\
\hline
\end{tabular}

Strains LP3041-6D and EMY1 are isogenic; strains 839, EMY7, EMY8, and JWY119 are isogenic; and strains YPH500 and JWY182 are isogenic.

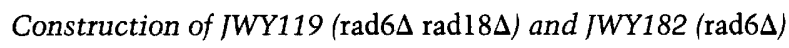 strains}

The genomic RAD18 gene from strain EMY8 and the genomic RAD6 gene from strain YPH500 were deleted by the method of gene replacement (Rothstein 1983). A ura3 mutant of EMY8 was obtained by selecting for growth on 5-fluoro-orotic acid (5-FOA) (Boeke et al. 1984). To delete the RAD18 gene, the resulting ura3 strain was transformed with a 6.6-kb EcoRI fragment from pJJ239 in which a 3.8 -kb BamHI-BglII fragment from pNKY51 (Alani et al. 1987) containing a hisG-URA3-hisG construct had been inserted into the BgIII site of pJJ193 (Jones et al. 1988). This deletes the RAD18 gene from position +130 in the open reading frame to 20 nucleotides beyond the termination codon. $U R A^{+}$transformants carrying the rad18A mutation, as verified by allelism test, were grown on 5-FOA to select for a

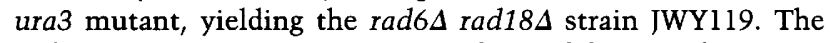
rad $6 \Delta$ mutation in YPH500 was obtained by transformation with a HindIII-BgIII DNA fragment of pTB64 (Reynolds et al. 1985) in which the 613-bp EcoRI fragment containing the entire $R A D 6$ open reading frame has been replaced by the $3.8-\mathrm{kb}$ his $G$ $U R A 3-$ his $G$ DNA fragment from pNKY51. Strain JWY182 was obtained by 5 -FOA treatment of $U R A^{+}$transformants showing allelism to rad6.

\section{Indirect immunofluorescence}

Determination of the cellular location of RAD6 and mutant Rad6 proteins was done by indirect immunofluorescence (Pringle et al. 1991). Affinity-purified antibodies to rad6-149 protein were used as the primary antibody. The secondary antibody used was goat anti-rabbit IgG conjugated to FITC (Sigma). As a control, cells used for immunofluorescence were also incubated with secondary antibody, in the absence of treatment with primary antibody, to make certain there was no cross-reactivity of cellular material to the secondary antibody. Cells were stained with 4',6'-diamidino-2 phenylindole (DAPI) to visualize the nucleus. A Leitz Laborlux D fluorescence microscope equipped with an Olympus PM-10AD photomicrographic system was used to visualize and photograph the fluorescence.

\section{Determination of $\beta$-Gal activity}

$R A D^{+}$strain YPH500, rad6 $\Delta$ strain JWY182, and rad6 6 strain JWY182 carrying plasmids pR661 (rad6 ${ }_{\Delta 1-9}$ ), pR615 (rad6-149), or pR616 (rad6-153) were each transformed with the Ub-X- $\beta$ Gal plasmid KEP268, KEP269, or KEP270. Minimal medium containing $2 \%$ galactose, instead of glucose, was inoculated with cells from an exponentially growing culture in glucosecontaining medium. The cells were grown overnight at $30^{\circ} \mathrm{C}$ and used to inoculate fresh galactose-containing medium. The cells were grown to $\sim 1 \times 10^{7}$ cells $/ \mathrm{ml}$ and then assayed for the level of $\beta$-Gal as described by Reynolds and Lundblad (1989).

\section{In vivo $\beta$-Gal degradation assay}

Pulse-chase experiments and immunoprecipitation of $\beta$-Gal proteins were carried out by a procedure similar to Bachmair et al. (1986). Briefly, $R A D^{+}$strain YPH500 and rad6 4 strain JWY182 carrying plasmids of interest (see above) were grown at $30^{\circ} \mathrm{C}$ in medium (for maintaining selection of plasmids) containing $2 \%$ galactose (in place of glucose) until the cell density was $\sim 1 \times 10^{7}$ cells $/ \mathrm{ml}$. Cells from $30 \mathrm{ml}$ of suspension were collected by filtration and washed three times at $30^{\circ} \mathrm{C}$ with 30 $\mathrm{ml}$ of selection medium lacking methionine. Cells were then suspended in $0.5 \mathrm{ml}$ of $40 \mathrm{~mm}$ potassium phosphate buffer $(\mathrm{pH}$ 7.4), $1 \%$ galactose, and labeled with $500 \mu \mathrm{Ci}$ of $\left[{ }^{35} \mathrm{~S}\right]$ methionine (Amersham; $>1000 \mathrm{Ci} / \mathrm{mmole}$ ) for $5 \mathrm{~min}$ at $30^{\circ} \mathrm{C}$. After the pulse period, the cells were collected by filtration, washed with $15 \mathrm{ml}$ of selection medium $\left(30^{\circ} \mathrm{C}\right)$, and suspended in $0.8 \mathrm{ml}$ of selection medium containing $0.5 \mathrm{mg} / \mathrm{ml}$ of cycloheximide and $10 \mathrm{~mm}$ methionine. Samples of $0.4 \mathrm{ml}$ were then withdrawn immediately and after a $15-\mathrm{min}$ chase period $10-$ and $15-\mathrm{min}$ samples, respectively, in Fig. 7), and added to $0.8 \mathrm{ml}$ of ice-cold buffer A [ $1 \%$ Triton X-100, $0.15 \mathrm{M} \mathrm{NaCl}, 5 \mathrm{~mm}$ EDTA, $50 \mathrm{~mm}$ HEPES (pH 7.5)] containing protease inhibitors (leupeptin, pepstatin, aprotinin, and chymostatin each at $20 \mu \mathrm{g} / \mathrm{ml}, 5 \mathrm{~mm}$ $n$-ethylmaleimide, $1 \mathrm{~mm}$ PMSF, $0.5 \mathrm{~mm}$ benzamidine), and cells were broken by vortexing vigorously for $3 \mathrm{~min}$ at $4^{\circ} \mathrm{C}$ in the presence of $0.4 \mathrm{ml}$ ( $\sim 0.7$ grams) of acid-washed glass beads $\mid 0.5$ $\mathrm{mm}$ ). Cellular debris was removed by centrifugation, and $\beta-\mathrm{Gal}$ was immunoprecipitated from $0.95 \mathrm{ml}$ of supernatant by addition of monoclonal antibodies to $\beta-\mathrm{Gal}$ (Promega) and incubation at $4^{\circ} \mathrm{C}$ for $1 \mathrm{hr}$ with rocking. Protein A-agarose $(50 \mu \mathrm{l})$ (Bio-Rad) was then added to the samples, and the incubation was continued for an additional $30 \mathrm{~min}$. The protein A-agarose pellet after a 3-sec centrifugation was washed three times with buffer A containing $0.1 \%$ SDS, suspended in SDS-electrophoresis sample loading buffer, boiled for $3 \mathrm{~min}$, and electrophoresed on a $6 \%$ SDS-polyacrylamide gel (Laemmli 1970). After electrophoresis, the gel was subjected to fluorography using EN $^{3}$ HANCE (Du Pont) and following the manufacturer's recommended procedure. 


\section{Protein purification}

All of the protein purification steps were carried out at $4^{\circ} \mathrm{C}$. Buffer A was $50 \mathrm{~mm}$ Tris- $\mathrm{HCl}(\mathrm{pH} 7.5)$ containing $10 \%$ sucrose, $200 \mathrm{~mm} \mathrm{KCl}, 10 \mathrm{~mm}$ EDTA, $10 \mathrm{~mm}$ 2-mercaptoethanol, and 10 $\mu \mathrm{g} / \mathrm{ml}$ of each of the following protease inhibitors: aprotinin, chymostatin, leupeptin, and pepstatin A. Buffer B was $20 \mathrm{~mm}$ $\mathrm{KH}_{2} \mathrm{PO}_{4}$ (pH 7.4) containing $10 \%$ glycerol, $0.5 \mathrm{~mm}$ EDTA, and $0.2 \mathrm{~mm}$ DTT. Chromatographic matrices were equilibrated in buffer B containing $150 \mathrm{mM} \mathrm{KCl}$.

The $\operatorname{rad6}_{\Delta 1-9}$ mutant protein was purified from extract of the rad6 $\Delta$ strain EMY8 harboring pR661 (ADC1::rad6 ${ }_{\Delta 1-9}$ ). Fifty grams of cells were disrupted through the use of a French press in $100 \mathrm{ml}$ of buffer $\mathrm{A}$, and the crude lysate was clarified by centrifugation $(100,000 \mathrm{~g}$ for $60 \mathrm{~min})$. The supernatant (fraction I) was diluted with $50 \mathrm{ml}$ of $10 \%$ glycerol before being applied onto DEAE-Sephacel $(1.6 \times 12.5 \mathrm{~cm})$; bound proteins were eluted with buffer B containing $400 \mathrm{mM} \mathrm{KCl}$. The protein pool (fraction II; $15 \mathrm{ml}$ ) was dialyzed against 1 liter of buffer B to lower the $\mathrm{KCl}$ concentration to $100 \mathrm{mM}$ and chromatographed on DEAE-Sephacel $(1 \times 5 \mathrm{~cm})$ by use of a $120-\mathrm{ml}$ gradient of $150-400 \mathrm{mM} \mathrm{KCl}$ in buffer $\mathrm{B}$. The rad6 $6_{\Delta 1-9}$ protein elutes from DEAE-Sephacel at $\sim 310 \mathrm{~mm} \mathrm{KCl}$, and the protein pool (fraction III; $9 \mathrm{ml}$ ) was diluted with $5 \mathrm{ml}$ of $10 \%$ glycerol and further fractionated on Mono Q (HR5/5) with a $25-\mathrm{ml}$ of $\mathrm{KCl}$ gradient from 150 to $500 \mathrm{~mm}$. The Mono-Q pool (fraction IV; $1 \mathrm{ml}$ with ionic strength of $400 \mathrm{mM} \mathrm{KCl}$ ) was concentrated to $200 \mu \mathrm{l}$ in Centricon-10 (Amicon) and subjected to molecular sizing on Sephadex G50 $(1 \times 25 \mathrm{~cm})$ to give fraction $\mathrm{V}(1.5 \mathrm{ml})$, which contained $20 \mu \mathrm{g}$ of nearly homogeneous $\mathrm{rad} 6_{\Delta 1-9}$ protein and was concentrated to $100 \mu \mathrm{l}$ and stored in small aliquots at $-70^{\circ} \mathrm{C}$

Wild-type RAD6 protein was purified as described by Sung et al. (1988).

\section{Immunoprecipitation}

Cell lysate was prepared from the ubr1 $\Delta$ rad $6 \Delta$ strain BBY68 harboring the plasmid pSOB44, in which UBR1 is overexpressed from the $A D C 1$ promoter. Cells were disrupted with a French press in buffer $\mathrm{C}[50 \mathrm{~mm}$ Tris- $\mathrm{HCl}(\mathrm{pH} 7.5), 1 \mathrm{~mm}$ EDTA, $50 \mathrm{~mm}$ $\mathrm{NaCl}$, and $0.5 \mathrm{mM} \mathrm{DTT}$, and $10 \mu \mathrm{g} / \mathrm{ml}$ of the protease inhibitors aprotinin, chymostatin, leupeptin, and pepstatin $\mathrm{A}]$ at $1 \mathrm{ml} / \mathrm{g}$ of cells and clarified by centrifugation $(100,000 \mathrm{~g}$ for $120 \mathrm{~min})$. To $0.3 \mathrm{ml}$ of extract was added $1 \mu \mathrm{g}$ of purified RAD6 or rad6 ${ }_{\Delta 1-9}$ protein, and after a 12-hr incubation on ice, $30 \mu \mathrm{l}$ of Affigel protein A (Bio-Rad) bearing $50 \mu \mathrm{g}$ of anti-RAD6 antibodies (Sung et al. 1988) was added. After mixing by rocking for $2 \mathrm{hr}$ at $4^{\circ} \mathrm{C}$, the immunoprecipitates were washed four times with $300 \mu \mathrm{l}$ of ice-cold buffer $C$ containing $5 \%$ glycerol but no protease inhibitors. Proteins were eluted from immunoprecipitates by a 5-min treatment with $50 \mu \mathrm{l}$ of $2 \%$ SDS at $37^{\circ} \mathrm{C}$ and subjected to SDSPAGE and immunoblot analysis.

\section{Assay of E3-dependent protein multiubiquitination and degradation}

Components of the cell-free proteolytic system-affinity-purified E1 and fractions containing E3 and the ubiquitin-specific protease-were obtained from rabbit reticulocytes as described (Sung et al. 1991). Assay mixtures $(25 \mu l)$ were assembled in 50 $\mathrm{mM}$ Tris- $\mathrm{HCl}(\mathrm{pH} 7.3)$ containing $5 \mathrm{~mm} \mathrm{MgCl}_{2}, 9.4 \mu \mathrm{M}$ ubiquitin, ${ }^{125}$ I-labeled $\beta$-lactoglobulin $\left(1.2 \times 10^{5} \mathrm{cpm}\right)$, an ATP-regenerating system ( $2 \mathrm{mM}$ ATP, $10 \mathrm{~mm}$ creatine phosphate, and $0.6 \mathrm{U} / \mathrm{ml}$ each of creatine phosphokinase and inorganic pyrophosphatase), $200 \mathrm{nM}$ RAD6 or $200 \mathrm{nM}$ to $1 \mu \mathrm{M}$ rad6 ${ }_{\Delta 1-9}$ protein,
$100 \mathrm{nM} \mathrm{El}$, E3 fraction (18 $\mu \mathrm{g}$ protein), and the protease fraction $\left(17 \mu \mathrm{g}\right.$ protein); multiubiquitination and degradation of the ${ }^{125} \mathrm{I}$ labeled protein substrate proceeded at $37^{\circ} \mathrm{C}$ for $60 \mathrm{~min}$. To process reaction mixtures for quantitation of substrate degradation, $30 \mu \mathrm{g}$ of BSA was added in $30 \mu \mathrm{l}$ followed by $30 \mu \mathrm{l}$ of $40 \%$ trichloroacetic acid. After a $10-\mathrm{min}$ incubation on ice, samples were spun at $4^{\circ} \mathrm{C}$ for $5 \mathrm{~min}$ in a microcentrifuge and the radioactivity of the supernatant was determined. To visualize the multiubiquitinated forms of the substrate, $10 \mu \mathrm{l}$ of reaction mixtures were withdrawn after $20 \mathrm{~min}$ of incubation and subjected to electrophoresis in $12.5 \%$ SDS-polyacrylamide gels and autoradiography.

\section{Assay of thioester formation}

Reaction mixtures $(10 \mu l)$ containing $6 \mu \mathrm{M}{ }^{125} \mathrm{I}$-labeled ubiquitin, $200 \mathrm{nM} \mathrm{El}$ and $500 \mathrm{nM}$ RAD6 or rad6 $6_{\Delta 1-9}$ protein in $50 \mathrm{~mm}$ Tris- $\mathrm{HCl}$ (pH 7.3), with $5 \mathrm{mM} \mathrm{MgCl}_{2}, 2 \mathrm{~mm} \mathrm{ATP}$, and $0.1 \mathrm{~mm}$ DTT were incubated at $30^{\circ} \mathrm{C}$ for $10 \mathrm{~min}$. After the addition of 10 $\mu \mathrm{l}$ of SDS buffer [ $4 \%$ SDS in $100 \mathrm{~mm}$ Tris- $\mathrm{HCl}(\mathrm{pH} 6.8)$ and $20 \%$ glycerol], samples were subjected to electrophoresis in $12.5 \%$ SDS-polyacrylamide gels and autoradiography.

\section{Other procedures}

Iodination of ubiquitin and $\beta$-lactoglobulin with sodium ${ }^{125} I$ (Amersham) using the chloramine T method was done as described (Sung et al. 1988). SDS-PAGE was carried out according to Laemmli (1970). Nitrocellulose blots were probed with $1 / 300$ dilution of the anti-ha monoclonal antibody 12 CA $5(2.5 \mathrm{mg} / \mathrm{ml}$; Berkeley Antibody) and 1/1000 dilution of affinity-purified polyclonal anti-RAD6 antibodies $(2.5 \mathrm{ml} / \mathrm{ml}$; Sung et al. 1988), and immunoblots were developed with protein A-HRP and 4-chloro-1-naphthol following the instructions of the supplier (Bio-Rad).

\section{Acknowledgments}

We thank E. Miller for expert technical assistance, C. Pickart and E. Kasperek for components of the rabbit reticulocyte proteolytic system, and A. Varshavsky and K. Madura for strain BBY 68 and plasmids $\mathrm{Ub}-X-\beta-\mathrm{Gal}$ and pSOB44. This work was supported by grants GM19261 from the National Institutes of Health and DE-FGO2-88ER60621 from the Department of Energy.

The publication costs of this article were defrayed in part by payment of page charges. This article must therefore be hereby marked "advertisement" in accordance with 18 USC section 1734 solely to indicate this fact.

\section{References}

Alani, E., L. Cao, and N. Kleckner. 1987. A method for gene disruption that allows repeated use of URA3 selection in the construction of multiply disrupted yeast strains. Genetics 116: $541-545$.

Bachmair, A., D. Finley, and A. Varshavsky. 1986. In vivo halflife of a protein is a function of its amino-terminal residue. Science 234: 179-186.

Bartel, B., I. Wünning, and A. Varshavsky. 1990. The recognition component of the $\mathrm{N}$-end rule pathway. EMBO I. 9:31793189.

Boeke, J.D., F. LaCroute, and G.R. Fink. 1984. A positive selection for mutants lacking orotidine-5'-phosphate decarboxylase activity in yeast: 5 -fluoro-orotic acid resistance. Mol. \& Gen. Genet. 197: 345-346.

Dingwall, C. and R.A. Laskey. 1991. Nuclear targeting se- 
quences-A consensus? Trends Biol. Sci. 16: 478-481.

Dohmen, R.J., K. Madura, B. Bartel, and A. Varshavsky. 1991. The N-end rule is mediated by the UBC2(RAD6) ubiquitinconjugating enzyme. Proc. Natl. Acad. Sci. 88: 7351-7355.

Field, J., J.I. Nikawa, D. Broek, B. MacDonald, L. Rodgers, I.A. Wilson, R.A. Lerner, and M. Wigler. 1988. Purification of a Ras-responsive adenylyl cyclase complex from Saccharomyces cerevisiae by use of an epitope addition method. Mol. Cell. Biol. 8: 2159-2165.

Finley, D. and V. Chau. 1991. Ubiquitination. Annu. Rev. Cell Biol. 7: 25-69.

Goebl, M.G., J. Yochem, S. Jentsch, J.P. McGrath, A. Varshavsky, and B. Byers. 1988. The yeast cell cycle gene CDC34 encodes a ubiquitin-conjugating enzyme. Science 241: 1331-1335.

Haas, A., P.M. Reback, G. Pratt, and M. Rechsteiner. 1990. Ubiquitin-mediated degradation of histone $\mathrm{H} 3$ does not require the substrate-binding ubiquitin protein ligase $E 3$, or attachment of polyubiquitin chains. I. Biol. Chem. 265: 21664-21669.

Heller, H. and A. Hershko. 1990. A ubiquitin-protein ligase specific for type III protein substrates. J. Biol. Chem. 265: 65326535.

Hershko, A. 1991. The ubiquitin pathway for protein degradation. Trends Biochem. Sci. 16: 265-268.

Ito, H., Y. Fukuda, K. Murata, and A. Kimura. 1983. Transformation of intact yeast cells treated with alkali cations. $J$. Bacteriol. 153: 163-168.

Jentsch, S., J.P. McGrath, and A. Varshavsky. 1987. The yeast DNA repair gene RAD6 encodes a ubiquitin-conjugating enzyme. Nature 329: 131-134.

Johnson, R.E., S.T. Henderson, T.D. Petes, S. Prakash, M. Bankmann, and L. Prakash. 1992. Saccharomyces cerevisiae $R A D 5$-encoded DNA repair protein contains DNA helicase and zinc-binding sequence motifs, and affects the stability of simple repetitive sequences in the genome. Mol. Cell. Biol. 12: 3807-3818.

Jones, J.S., S. Weber, and L Prakash. 1988. The Saccharomyces cerevisiae RAD18 gene encodes a protein that contains potential zinc finger domains for nucleic acid binding and a putative nucleotide binding sequence. Nucleic Acids Res. 16: 7119-7131.

Koken, M., P. Reynolds, D. Bootsma, J. Hoeijmakers, S. Prakash, and L. Prakash. 1991a. Dhr6, a Drosophila homolog of the yeast DNA-repair gene RAD6. Proc. Natl. Acad. Sci. 88: 3832-3836.

Koken, M.H.M., P. Reynolds, I. Jaspers-Dekker, L. Prakash, S. Prakash, D. Bootsma, and J.H.J. Hoeijmakers. 1991b. Structural and functional conservation of two human homologs of the yeast DNA repair gene RAD6. Proc. Natl. Acad. Sci. 88: $8865-8869$

Laemmli, U.K. 1970. Cleavage of structural proteins during the assembly of the head of bacteriophage T4. Nature 227: 680685.

Morrison, A., E.J. Miller, and L. Prakash. 1988. Domain structure and functional analysis of the carboxy-terminal polyacidic sequence of the RAD6 protein of Saccharomyces cerevisiae. Mol. Cell. Biol. 8: 1179-1185.

Pickart, C.M. and I.A. Rose. 1985. Functional heterogeneity of ubiquitin carrier proteins. J. Biol. Chem. 260: 1573-1581.

Pickart, C.M. and A.T. Vella. 1988. Levels of active ubiquitin carrier proteins decline during erythroid maturation. I. Biol. Chem. 263: 12028-12035.

Prakash, S., P. Sung, and L. Prakash. 1990. Structure and function of DNA repair genes of Saccharomyces cerevisiae. In The eukaryotic nucleus: Molecular structure and macromo- lecular assemblies (ed. P. Strauss and S. Wilson), pp. 275292. The Telford Press, Caldwell, NJ.

Pringle, J.R., A.E.M. Adams, D.G. Drubin, and B.K. Haarer. 1991. Immunofluorescence methods for yeast. Methods Enzymol. 194: 565-602.

Qin, S., B. Nakajima, M. Nomura, and S.M. Arfin. 1991. Cloning and characterization of a Saccharomyces cerevisiae gene encoding a new member of the ubiquitin-conjugating protein family. I. Biol. Chem. 266: 15549-15554.

Reynolds, A. and V. Lundblad. 1989. Yeast vectors and assays for expression of cloned genes. In Current protocols in molecular biology (ed. F.M. Ausubel, R. Brent, R.E. Kingston, D.D. Moore, J.G. Seidman, J.A. Smith, and K. Struhl), vol. 2, pp. 13.6.1-13.6.4. Wiley Interscience, New York.

Reynolds, P., S. Weber, and L. Prakash. 1985. RAD6 gene of Saccharomyces cerevisiae encodes a protein containing a tract of 13 consecutive aspartates. Proc. Natl. Acad. Sci. 82: 168-172.

Reynolds, P., M.H.M. Koken, J.H.J. Hoeijmakers, S. Prakash, and L. Prakash. 1990. The rhp6 ${ }^{+}$gene of Schizosaccharomyces pombe: A structural and functional homolog of the RAD6 gene from the distantly related yeast Saccharomyces cerevisiae. EMBO /. 9: 1423-1430.

Rothstein, R.J. 1983. One-step gene disruption in yeast. Methods Enzymol. 101: 202-211.

Schiestl, R. H., S. Prakash, and L. Prakash. 1990. The SRS2 suppressor of rad6 mutations of Saccharomyces cerevisiae acts by channeling DNA lesions into the RAD52 DNA repair pathway. Genetics 124: 817-831.

Seufert, W. and S. Jentsch. 1990. Ubiquitin-conjugating enzymes UBC4 and UBC5 mediate selective degradation of short-lived and abnormal proteins. EMBO I. 9: 543-550.

Seufert, W., J.P. McGrath, and S. Jentsch. 1990. UBC1 encodes a novel member of an essential subfamily of yeast ubiquitinconjugating enzymes involved in protein degradation. $E M B O$ I. 9: 4535-4541.

Sharon, G., B. Raboy, H.A. Parag, D. Dimitrovsky, and R.G. Kulka. 1991. RAD6 gene product of Saccharomyces cerevisiae requires a putative ubiquitin protein ligase $\left(E_{3}\right)$ for the ubiquitination of certain proteins. J. Biol. Chem. 266: 15890-15894.

Sherman, F., G.R. Fink, and J.B. Hicks. 1986. Methods in yeast genetics: Laboratory course manual. Cold Spring Harbor Laboratory, Cold Spring Harbor, New York.

Sikorski, R.S. and P. Hieter. 1989. A system of shuttle vectors and yeast host strains designed for efficient manipulation of DNA in Saccharomyces cerevisiae. Genetics 122: 19-27.

Sung, P., S. Prakash, and L. Prakash. 1988. The RAD6 protein of Saccharomyces cerevisiae polyubiquitinates histones, and its acidic domain mediates this activity. Genes \& Dev. 2: $1476-1485$.

-1990. Mutation of cysteine- 88 in the Saccharomyces cerevisiae RAD6 protein abolishes its ubiquitin-conjugating activity and its various biological functions. Proc. Natl. Acad. Sci. 87: 2695-2699.

Sung, P., E. Berleth, C. Pickart, S. Prakash, and L. Prakash. 1991. Yeast RAD6 encoded ubiquitin conjugating enzyme mediates protein degradation dependent on the $\mathrm{N}$-end-recognizing E3 enzyme. EMBO I. 10: 2187-2193.

Wing, S.S., F. Dumas, and D. Banville. 1992. A rabbit reticulocyte ubiquitin carrier protein that supports ubiquitin dependent proteolysis $\left(E 2_{14 \mathrm{~K}}\right)$ is homologous to the yeast DNA repair gene RAD6. J. Biol. Chem. 267:6495-6501.

Zoller, M.J. and M. Smith. 1984. Oligonucleotide-directed mutagenesis: A simple method using two oligonucleotide primers and a single-stranded DNA template. DNA 3: 479-488. 


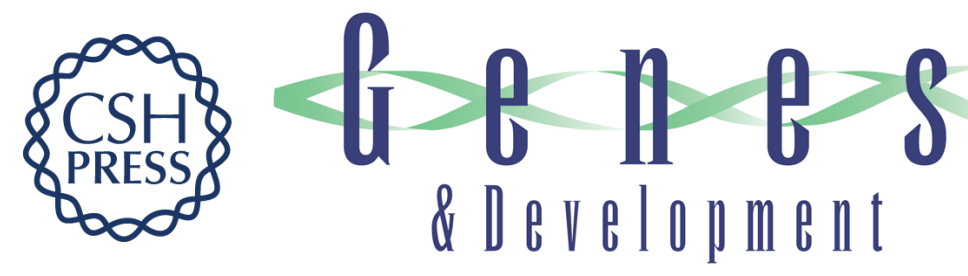

\section{The extremely conserved amino terminus of RAD6 ubiquitin-conjugating enzyme is essential for amino-end rule-dependent protein degradation.}

J F Watkins, P Sung, S Prakash, et al.

Genes Dev. 1993, 7:

Access the most recent version at doi:10.1101/gad.7.2.250

References This article cites 37 articles, 22 of which can be accessed free at: http://genesdev.cshlp.org/content/7/2/250.full.html\#ref-list-1

License

Email Alerting Receive free email alerts when new articles cite this article - sign up in the box at the Service top right corner of the article or click here.

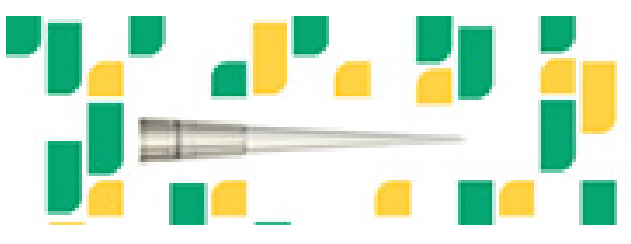

Focused on your science. 